\title{
非定常自由表面流中の正角柱に働く流体力 HYDRODYNAMIC FORCE EXERTING ON A SQURE PILLAR IN UNSTEADY FREE SURFACE FLOWS
}

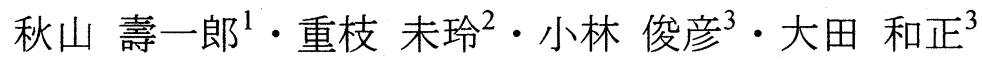 \\ Juichiro AKIYAMA, Mirei SHIGE-DA, Toshihiko KOBAYASHI and Kazumasa OOTA \\ ${ }^{1}$ 正会員 Ph.D 九州工業大学教授 工学部建設社会工学科（广804-8550 北九州市戸畑区仙水町1-1） \\ 2学生員 修士 (工) 九州工業大学大学院 工学研究科博士後期課程 (同上) \\ 3学生員 学士(工) 九州工業大学大学院 工学研究科博士前期課程 (同上)
}

\begin{abstract}
Flow characteristics of 1-D dam break flows and hydrodynamic force exerted on a square pillar placed by the flow were measured by a 2-component load cell. The angle of attack of the pillar and the ratio of channel width to the pillar width (blockage-ratio) were kept 0 degree and 10, respectively. It is found that the velocity profile of the flow with no presence of a pillar follows approximately logarithmic velocity distribution on the smooth wall, and that the ratio of surface to depth-averaged velocity is about 1.12. The magnitude of drag coefficient of the pillar 1-D dam break flows is compared with that of steady uniform flows. The former increases very slowly with $t_{*}$ after $t_{*}>70$.
\end{abstract}

Key Words : Drag coefficient, square pillar, unsteady free surface flow, PTV

\section{1. はじめに}

ここ数年，世界各地で局地的集中豪雨による洪水災害 が頻発している。わが国では推定8,500億円の総被害額と なった2000年9月の東海豪雨災害が記憶に新しいが，その 後も隣国の韓国や台湾などで洪水災害が発生し，甚大な 被害をもたらした．このように，予想を超えるような集 中豪雨とそれに伴う洪水汇濫が頻発するようになってき た現在では，堤防の強化等のハード的な洪水汇濫対策に は自ずと限界があり，洪水が氾濫した場合を想定し，そ の被害を最小限に抑えるソフト面での対策，つまり氾濫 原管理がこれまでにも増して重要になってきた1), 2).

わが国の都市の多くは, 周知のとおり河川の汇濫区域 に位置しており，海に臨しで位置する大都市も少なくな い. 異常気象の深化に伴う極度の集中豪雨が発生した場 合には，ダムや堤防の決壊による非定常性の強い洪水氾 濫流により, 河川に隣接する市街地では家屋の倒壊や流 失等の甚大な被害をもたらす可能性がある。.また，洪水 汇濫に較べて発生頻度は稀であるが，海底地震による大 規模な津波が発生した場合では，陸上に打ち上がった津 波汇濫流により同等あるいはそれ以上の被害をもたらす ことは1993年7月の奥尻島での津波災害の例からも明らか であろう。従って, 被害軽減を目的とした効果的な氾濫 原管理を行うためには，河川汇濫あるいは津波氾濫を問
わず，汇濫危険区域における家屋や道路等が密集する市 街地での汇濫流挙動の的確な把握と家屋の危険度評価が これまでにも増して重要になると考えられる.

このような観点から, 著者らは非定常性の強い汇濫流 の挙動を的確に予測できるだけでなく, 氾濫流が家屋に 及ぼす外力までも水理学的な根拠に基づき評価できる市 街地汇濫流シミュレーションモデルの構築を行ってい る4， 5)。このためにも非定常流中における物休や物体群が どのような流体力や衝撃力を受けるのかについて充分に 把握する必要があるが，以下で述べるように，これにつ いてはほとんどわかっていないのが害状であり, 定常流 中で得られた流体力の結果を非定常流へ準適用している のが実態である゙ 2).

等流中の家屋に働く流体力については，それを角柱に 置換えた状態での室内実験より, 高橋ら ${ }^{3}$, 栗城ら ${ }^{7}$, 福

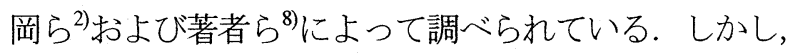
非定常自由表面流(以下では必要な場合を除き非定常流と 略称する)による流体力については，2次元鉛直壁への サージフロントの衝突による衝撃力を対象として, Fukui et al. ${ }^{9)}, \operatorname{Cross}^{10)}$ ，松富 ${ }^{11)}$, Cumberbatch ${ }^{12)}$ 等によって調心 られている. しかし, 非定常流中における物体について は, Alaviによって得られた円柱あるいは角柱にサージフ ロントが衝突したときの衝撃力の大まかな結果がCross ${ }^{10}$ の付録に示されている程度であり，そこで指摘されてい るように, この結果から有益な情報を得ることは難しい. 


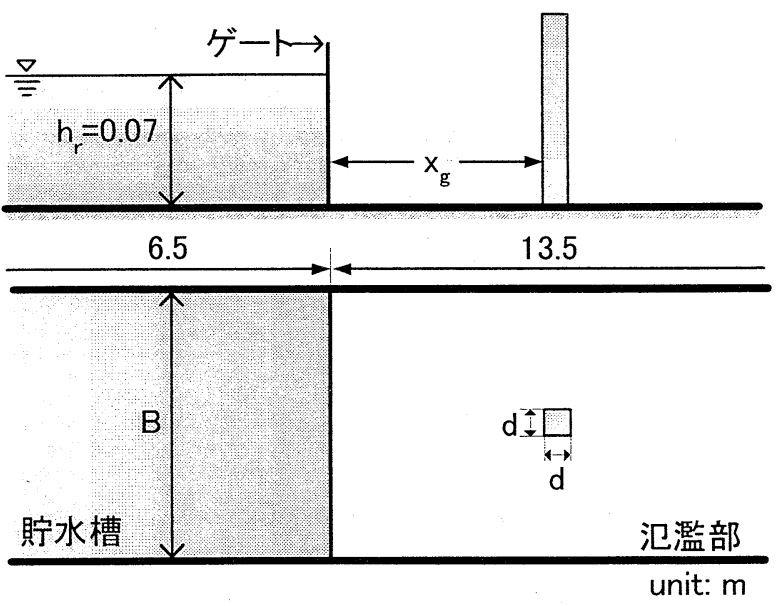

図-1 実験装置

本研究は，以上のような背景を踏まえ，非定常性の強 い自由表面流中における非水没状態の角柱に働く流体力 や抵抗係数を明らかにすることを目的として実施したも のである.

\section{2. 実験}

非定常自由表面流としては，ダムや堤防の決壊による 洪水汇濫あるいは津波汇濫を想定し, 非定常性の強い夕゙ ム破壊流れを採用した。.また，ダム破壊流れが初期条件 の設定が正確かつ容易な非定常自由表面流であることも これを用いた理由の一つである.

実験装置は，図-1に示すような，上流側から6.5mの位

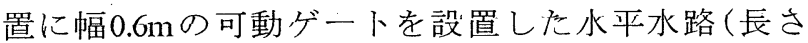
$L=20.0 \mathrm{~m}$ ，幅 $B=0.6 \mathrm{~m}$ ) であり，ゲートの上流側(貯水槽)に は水深 $0.07 \mathrm{~m}$ の水が貯えられており，下流側(汇濫部)は水 の無いドライベッド状態である，なお，水路底面にはア クリル板が敷詰められている．開放時間0.033秒以内で可 動ゲートをほぼ瞬間的に引き上げることで，氾濫部にド ライベッド上のダム破壊流れを発生させた.

実験は，汇濫原に角柱が設置されていない状態 (Case0) と設置された状態(Case1 3)について実施した．角柱が設 置された場合では，図-1に示すようにゲートから正角柱 （幅 $d=0.06 \mathrm{~m}$ ) までの距離 $x_{g}$ を $1.0 \mathrm{~m}$ (Case 1$) ， 1.65 \mathrm{~m}$ (Case2) お よび2.0m(Case3)の3通りに変化させた。 なお，角柱は水 深より高い非水没状態であり，迎角 $\alpha=0^{\circ}$ およびblockageratio $B / d=10$ の一定值に設定してある.

表面流速 $V_{\mathrm{s}}$, 水深平均流速 $V$, 水深 $九$ よび抗力 $D$ を算定 するための計測をそれぞれ以下の要領で行った．特に， 流速と水深の測定は，ドライベッド上の汇濫流であるこ とを踏まえた計測を行った，すなわち，表面流速 $V_{\mathrm{s}}$ は直 径 $0.006 \mathrm{~m}$ の多数の発泡スチロール球を投入し, CCDカメ ラで水路上部から撮影した画像(図-2a) をPTVで解析して 求めた. また，水深方向の流速uはレーザ一光を所定の位 置に照射し直径 $200 \mu \mathrm{m}$ の粒子を可視化し，CCDカメラで

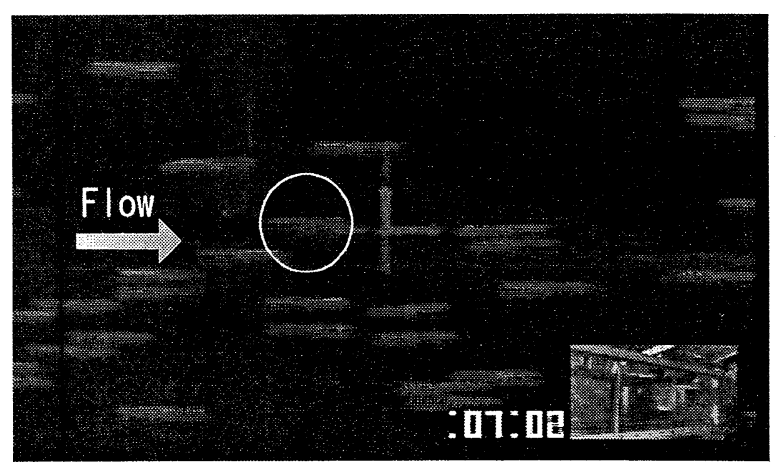

(a) 表面流速 $V_{\mathrm{s}}$

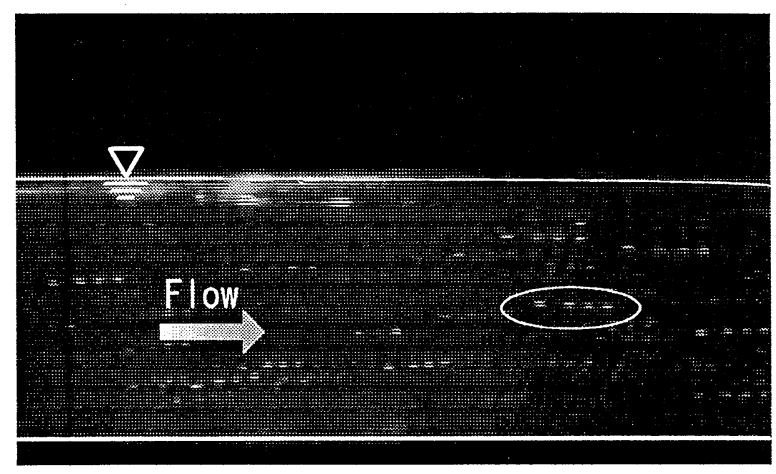

(b) 流速 $u$
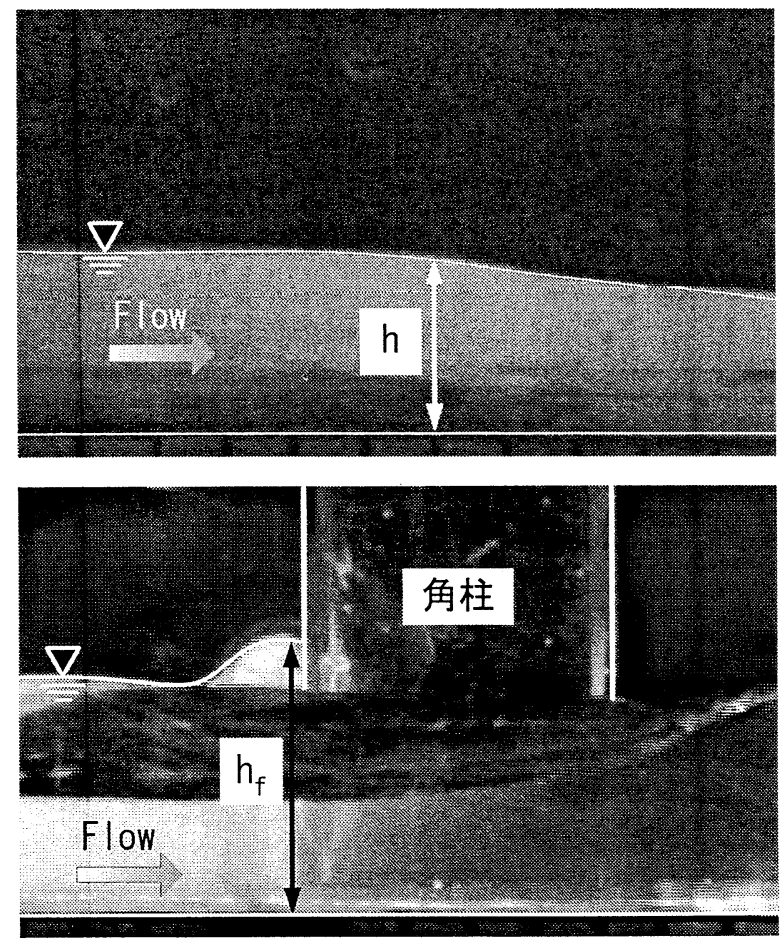

(c) 水深 $h$ (上: Case0, 下: Case1 3)

図-2 計測方法

水路側面から撮影した画像(図-2b)をPTVで解析して求め た。なお，流速の測定は水路の中心軸上の測定位置の角 柱を取り除いた中心地点で行った，さらに，水深んはレー ザー光を所定の位置に照射し，水路側面からCCDカメラ で撮影した画像(図-2c)の解析より求めた。 その際，水表 面を明瞭に識別できるようにウラニンで水を着色した. 
以上の計測は，角柱が設置された状態と設置されてい ない状態のいずれに対しても行った，なお，角柱が設置 されていない場合 (Case0)の水深計測は角柱を取り除いた 中心地点で, 設置されている場合は角柱の前面および後 面で行った. 抗力Dは2分力計を用いて算定した. 抗力測 定のサンプリング間隔は0.01秒，サンプリング時間は20秒 である. 各測定はそれぞれ同一条件下で最低5回行いデー タの信頼性を高めた.

\section{3. 実験結果}

図-3は，汇濫原に角柱が設置されていない状態におけ る各測点 $x_{g}$ での流速分布 $u / u_{*}$ について検討を加えたもので ある.ここに，uは摩擦速度であり，カルマン定数には 0.4 としている．同図より，1次元ダム破壊流れにおいても無 次元経過時間 $t_{*}\left(=t /\left(h_{0} / g\right)^{1 / 2}\right)$ と測定位置とにほぼ無関係に, $u / u_{*}$ は式(1)の滑面対数分布則 ${ }^{12)}$ でおおよそ表せることが わかる. 摩擦速度 $u_{*}$ はマニングの粗度係数切ら算定して おり, その值としてはn0.0095としている. アクリル板の 標準的なマニングの粗度係数はnー0.01であり，この程度の 粗度係数の違いは誤差の範囲であると考えられることか ら，ドライベッド上の1次元ダム破壊流れにおいても約 $t_{*}$ $\geqq 50$, 寸なわち $t \geqq 4.2 \mathrm{~s}$ では式(1) の開水路等流の流速分布 が適用できることがわかる.

$$
\frac{u}{u_{*}}=\frac{1}{\kappa} \ln \frac{u_{*} y}{v}+5.3
$$

図-4は，発砲スチロール球を用いて得られた各測点で の表面流速 $V_{\mathrm{sp}}$ 上流速分布より得られた表面流速 $V_{\mathrm{su}}$ との比 である表面流速比 $V_{\mathrm{sp}} / V_{\mathrm{su}}$ の時系列を示したものである.こ れより, 測定位置と $t_{*}$ とは無関係に $V_{\mathrm{sp}} / V_{\mathrm{su}} \fallingdotseq 1.0$ となってい ることから，非定常性の強いダム破壊流れに対しても発 砲スチロール球を用いたPTV解析が充分な精度を有して いることが確認できる．以下では， $V_{\mathrm{sp}}$ もって表面流速 $V_{\mathrm{s}}$ と定義する.

図-5は，氾濫原に角柱が設置されていない状態におけ る各測点でのRitter 解 ${ }^{13)} よ り$ 得られる水深平均流速 $V_{\mathrm{R}}$ と本 研究で得られた流速分布を積分することで求めた水深平 均流速 $V$ との比である水深平均流速比 $V_{\mathrm{R}} / V$ 時系列を,

図-6はRitter 解より得られる水深と本研究で得られた水深 との比である水深比 $h_{\mathrm{R}} / h$ の時系列を示したものである. 図一7は, 各測点での表面流速 $V_{\mathrm{s}}$ と水深平均流速 $V$ との比で ある表面流速比 $V_{s} / V$ 時系列を示したものである.

これらの図より， $V_{\mathrm{R}} / V$ と $V_{\mathrm{s}} / V$ のいずれもtにははとんど 依存せずほぼ一定值を取り，それぞれ $V_{\mathrm{R}} / V \fallingdotseq 1.12$ および $V_{s} / V \fallingdotseq 1.08$ のうになることがわかる。 著者ら ${ }^{8}$ によれば 等流での $V_{\mathrm{s}} / V$ は約1.11であり, この值は式(1)から得られ る $V_{\mathrm{s}} V$ と一致する. 本結果と等流の結果とを比較すると, 2次元ダム破壊流れの $V_{s} / V$ 方が僅かに大きくなっている

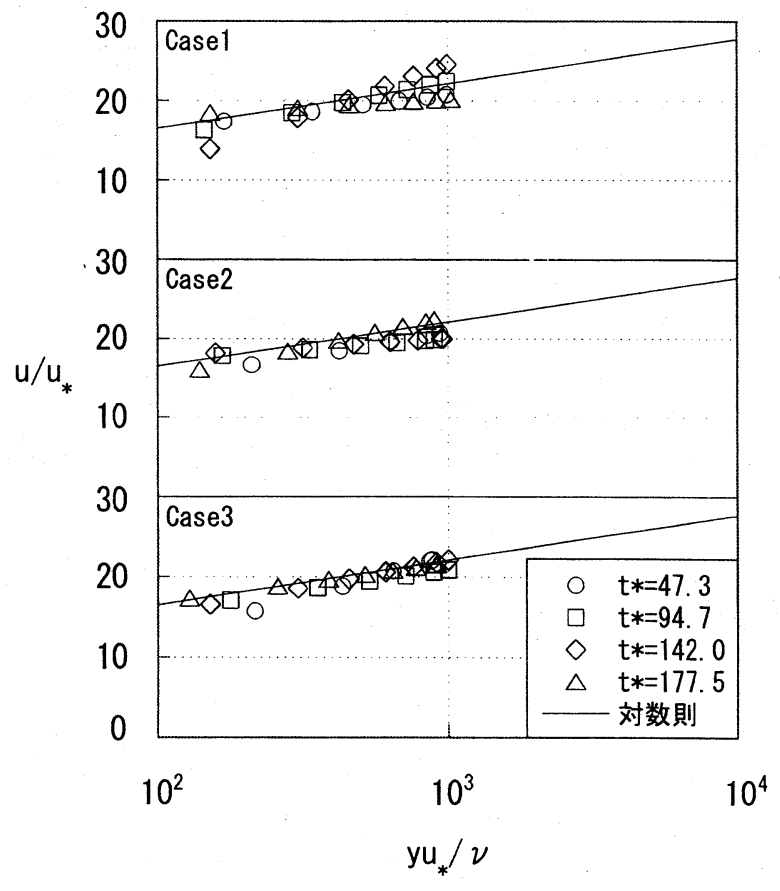

図-3 ダム破壊流れの流速分布 $u / u_{*}$

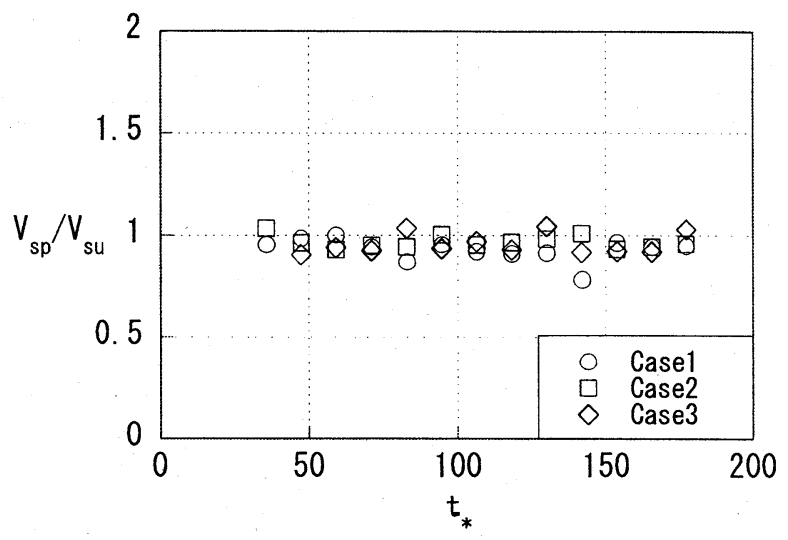

図-4 表面流速比 $V_{\mathrm{sp}} / V_{\mathrm{su}}$ の時采列

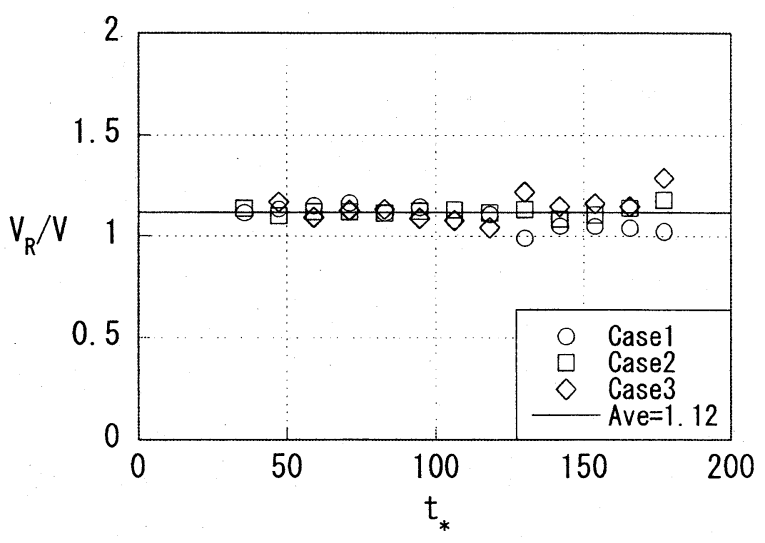

図-5 水深平均流速比 $V_{\mathrm{R}} / V$ の時系列

が，ほぼ同様な值であると考えてよい，また， $h_{\mathrm{R}} / h$ は約 $t *$ $\leqq 50$ を除いて約 0.8 のほぼ一定值を取っている. 約 $t$ ミ50で $h_{\mathrm{R}} / h$ が $h_{\mathrm{R}} / h=0.8$ のラインからはずれるのは, Ritter解では フロントの水面形状を表せないためである，なお， $V か ゙ V_{\mathrm{R}}$ と, hが $h_{\mathrm{R}}$ と一致しないのは, Ritter 解で考慮されていな い底面粗度の影響であると考えられる。 


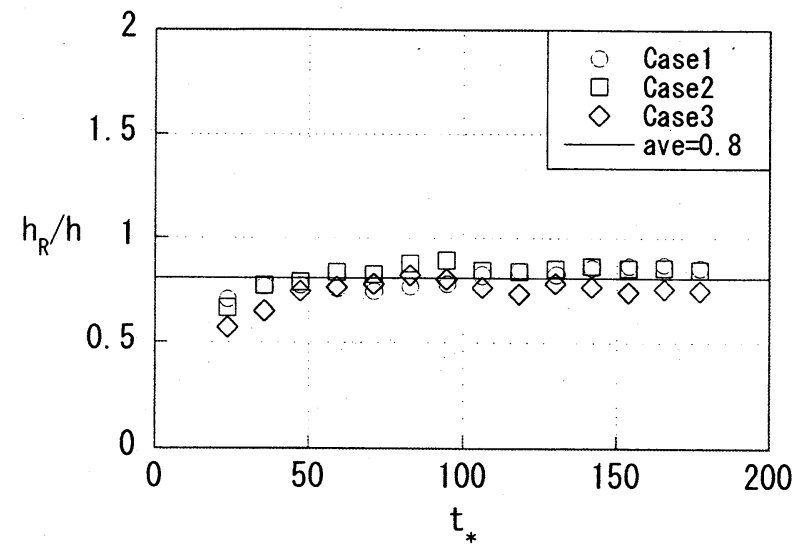

図-6 水深比 $h_{R} / h \sigma$ 時系列、各測点

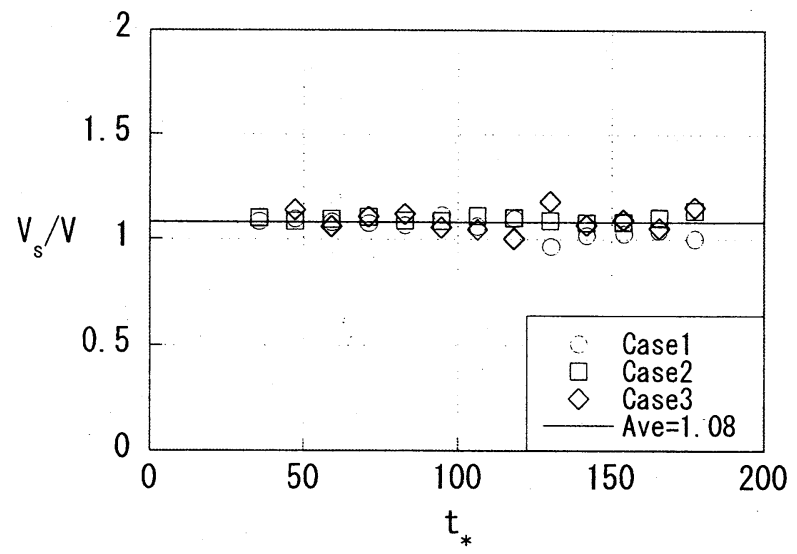

図-7 表面流速比 $V_{s} / V$ の時系列

図-8は, 角柱の前面水深 $h_{\mathrm{f}}$, 水深平均流速 $V$, 抗力 $D$ お よび抵抗倸数 $C_{d}$ (時采列を示したものである.ここに， $C_{d}=2 D /\left(\rho V^{2} A\right), \rho=$ 水の密度および $A=$ 角柱の投影面積 $\left(=d h_{\mathrm{f}}\right)$ である. なお，代表流速としては角柱が設置された 測点でのCase0の水深平均流速 $V$ 用いている. 同図より, 測定位置とは無関係に衝突直後から $t_{*} \fallingdotseq 180$ までの区間で は， $h_{\mathrm{f}}$ がほぼ一定值を取ること，Vは $t_{*}$ の増加とともに減 少すること，Dはt $t_{*}$ の増加とともに若干減少すること， $C_{d}$ は $t_{*}$ の増加とともに徐々に増加すること，などがわかる. 加えて，変動は見られるものの，全体的にDとC $C_{d}$ はCasel $\rightarrow 2 \rightarrow 3$ 順に小さくなっていることが見て取れる．同図 において, 画像解析の精度上の限界のため角柱に洪水波 が衝突する直後のデータを得ることは難しかったので, ここには示されていない，また，図-8aから明らかなよう に，洪水波の衝突から前面水深 $h_{\mathrm{f}}$ 減衰し始める $t_{*} \geqq 177$ で の諸量んは計測しておらず，その傾向は不明である。これ は, 本研究が非定常性の強い状態での流体力の推定を目 的としているためである.

図-9は, 抵抗係数值 $C_{d}$ を開水路等流での抵抗係数 $\left(C_{d s}=\right.$ $2.41)^{8)}$ で正規化した抵抗係数比 $C_{d} / C_{d s}$ の時系列を示したも のである.この $C_{c s}$ の值としては $B / d の$ 影響を考慮して, $B / d=10$ の值を採用している. 同図より, 貯水槽の上流端 で反射した波が影響しないt $t$ ○177までの間では, $C_{d} / C_{d s}$ は $t_{*}$ の増加とともに $t_{*} \fallingdotseq 70$ までは急激に増加するが，その後 は緩やかに増加し, $C_{d} / C_{d s} \fallingdotseq 0.5$ 程度の值となっているこ とがわかる。

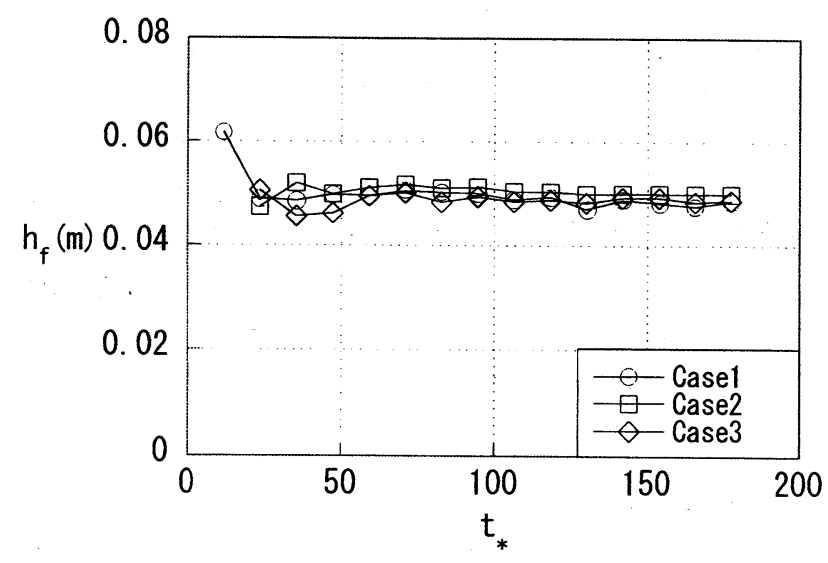

（a）角柱の前面水深 $h_{f}$

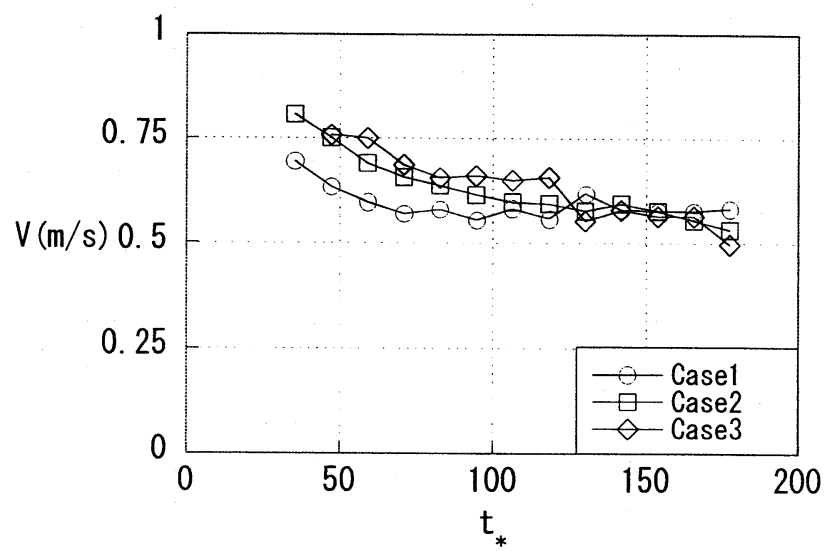

（b）水深平均流速 $V$

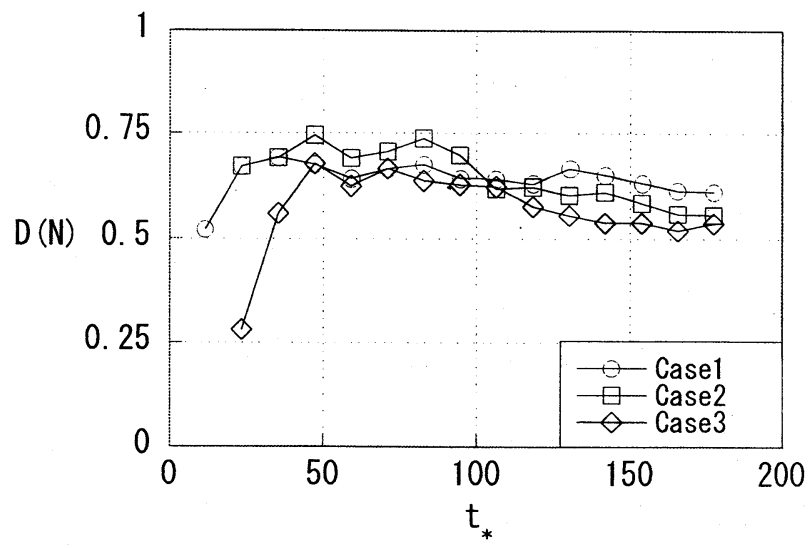

(c) 抗力 $D$

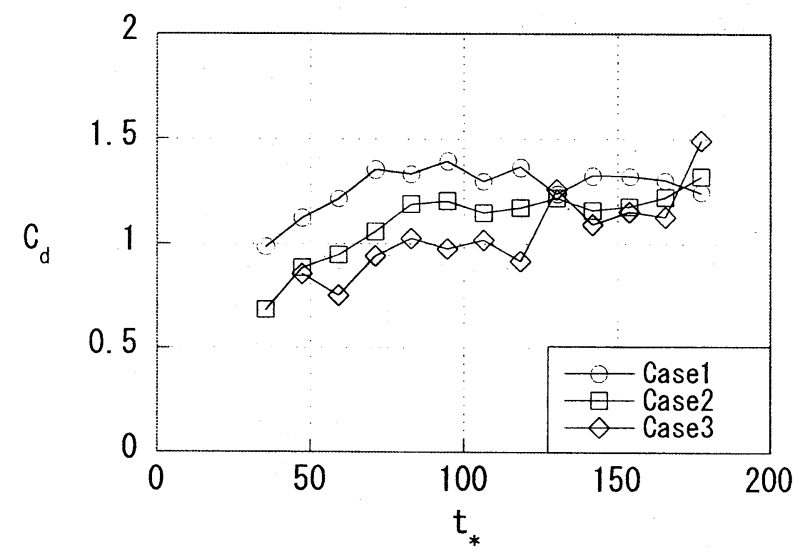

(d) 抵抗係数 $C_{d}$

図-8 各特性量の時系列 


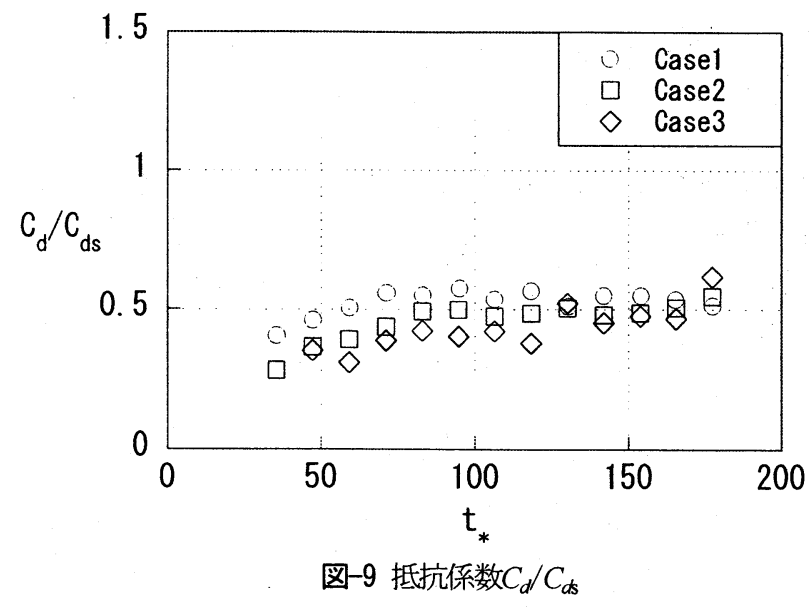

本実験装置では貯水槽の長さに $6.5 \mathrm{~m}$ という制限がある ため，反射波のない状態での $t_{*}>178$ の実験結果を得るこ とはできない，そこで，参考文献)の数值モデルを用いて 貯水槽を充分に長くした条件下で数值実験を行い，その 状態での $C_{d} / C_{d s}$ の举動について調べた. 図-10a，b，cおよ

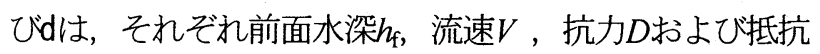
係数比 $C_{d} / C_{d s}$ について実験值と計算值を比較したものであ る. いずれのケースでも角柱の設置位置がゲートにかな り近いので，実験結果が良好に再現されているとは必ず しも言えないが， $t_{*}$ の増加とともに $C_{d} / C_{d s} \fallingdotseq 1.0$ に漸近する 傾向は見て取れる. $C_{d} / C_{c s}$ に関する実験結果の傾向を尊重 すると, 最終的には $C_{d} / C_{d s} \doteqdot 1.0$ となると推察されるが, $t_{*}$ $>70$ では $t$ に対する抵抗係数の増加が極めて緩やかである ため, かなりの長時間にわたって $C_{d} / C_{d s} \fallingdotseq 0.5$ 程度の值を 取ると予測される. 非定常流の流体力で問題しなる付加 質量の影響はさほど大きくなく, 等流に比して抵抗係数 が小さくなる理由は今のところは不明である.この点に ついては, メカニズムも含めて今後より梁く検討を加え ていく必要がある.

抵抗倸数比 $C_{d} / C_{d b}$ の傾向については, 図-9のように無次 元経過時間 $t_{*}$ の関係よりも, 流れの状態を表すパラメータ も含めた関係として捉えた方が好ましいと考えられる. そこで, $C_{d} / C_{d s}$ と流れの状態を表すパラメータ $\Phi\left(=F_{r}^{-2}(\Delta h / d)\left[\left(d / h_{\mathrm{f}}\right)\left(2-(\Delta h / d)\left(d / h_{\mathrm{f}}\right)\right)\right] / C_{d s}\right)$ との関係 について調べたものが図-11である.ここに， $F_{r}=$ 角柱の前 面水深に基づくFroude数 $\left(=V /\left(g h_{\mathrm{f}}\right)^{1 / 2}\right), \Delta h=h_{\mathrm{f}}-h_{\mathrm{b}}$ および 的は角柱の後面水深である. Фは角柱の前後面で静水圧分 布が成立すると仮定した圧力差から得られる関係を $C_{d s}$ で 除したものである. 図-10aで解がほぼ0.049の一定值を取 ることを勘案すると， $\Phi は F_{r}$ と非定常性を表すパラメータ $\Delta h / d に$ 依存している. 同図で示された矢印は， $t_{*}$ が増加す る方向を示している. また, 図中の実線は, 静水圧分布 から得られる関係である. これより， $t_{*}$ の増加とともに

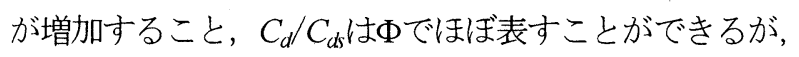
Фが大きくなると若干のずれが生じることがわかる. ただ し, 非定常流中での角柱後面の流況は極めて複雑であり， 本研究で得られた このため, $\Delta h / d の$ 值が必ずしも適正に評価できていない

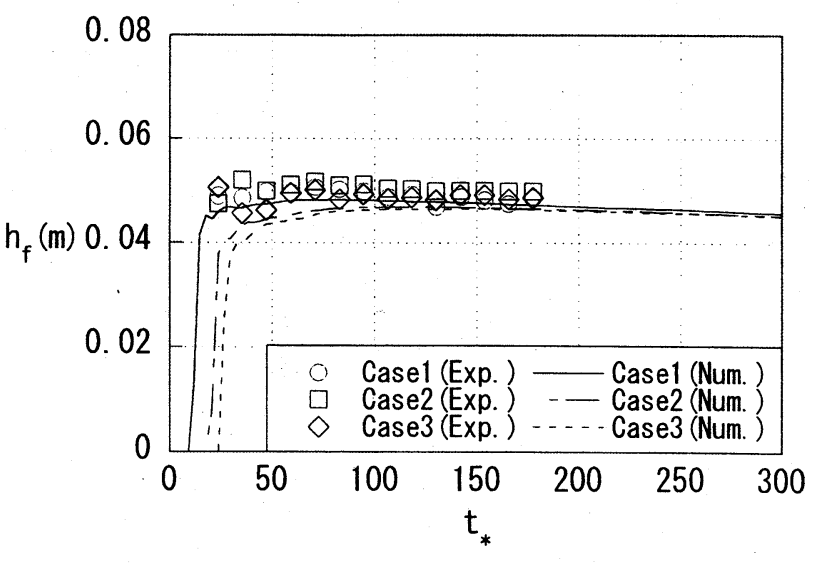

（a）角柱の前面水深 $h_{f}$

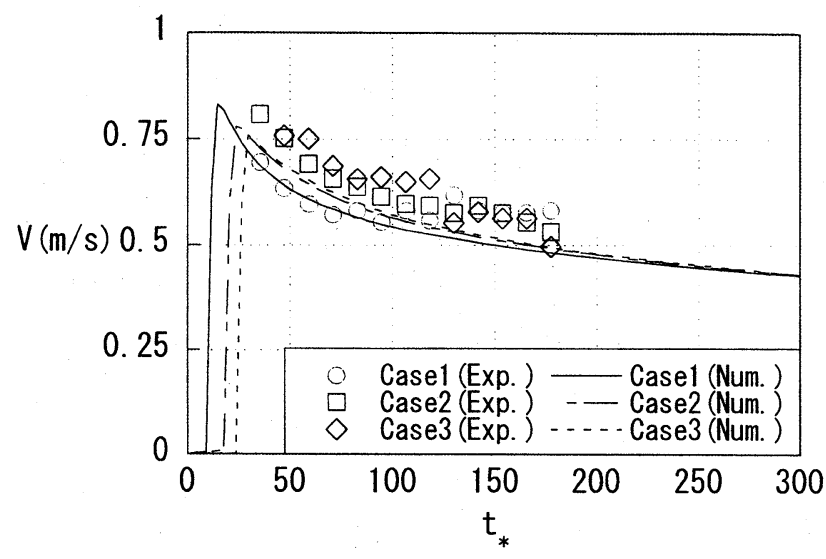

(b) 水深平均流速 $V$

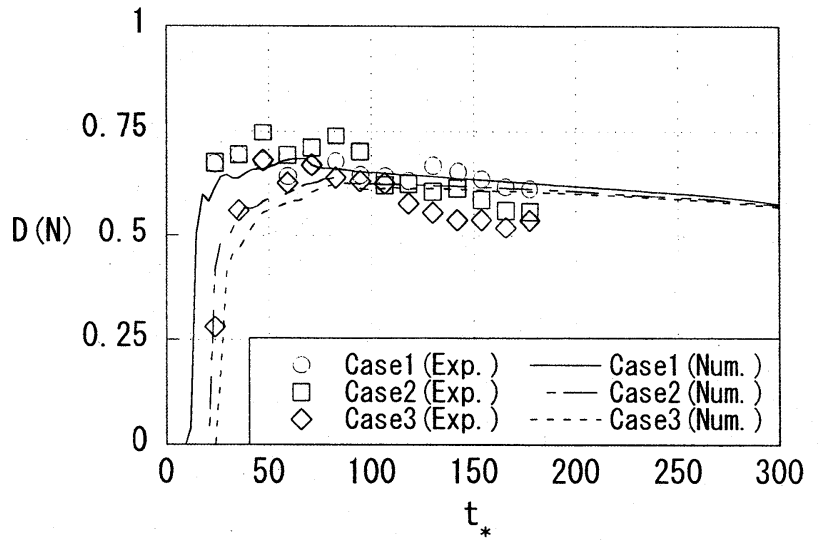

(c) 抗力 $D$

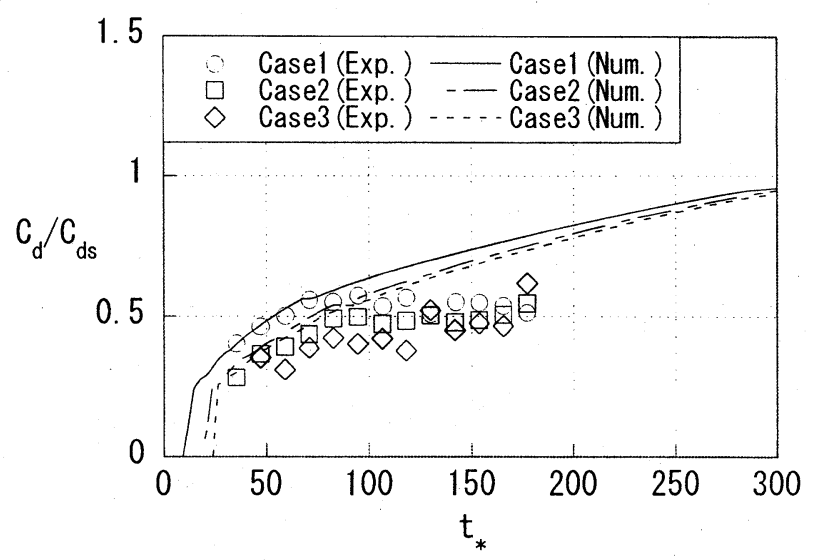

(d) 抵抗係数 $C_{d}$

図-10 各特性量の実験値と数值実験の時系列 


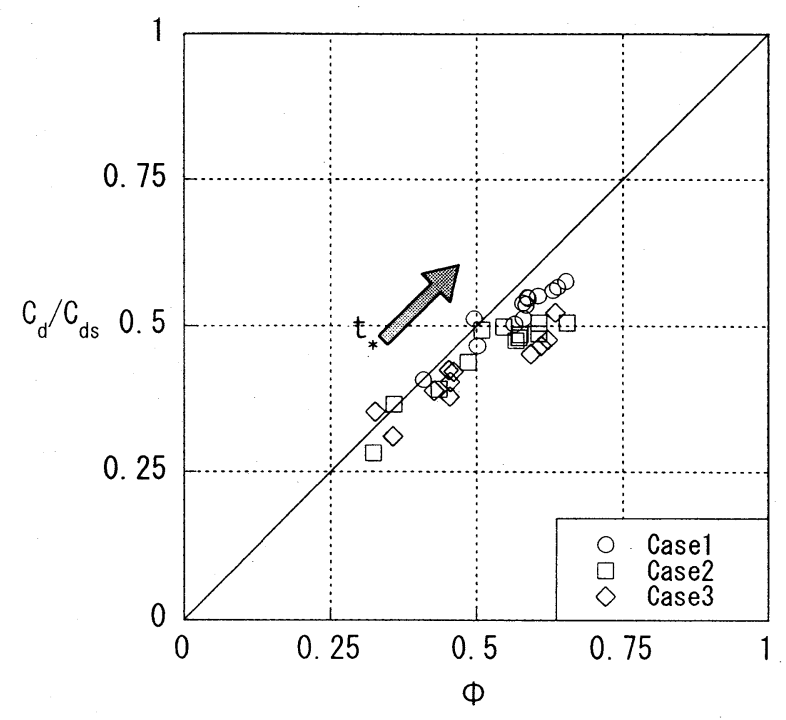

図-11 抵抗釈数比 $C_{d} / C_{c \mathrm{~b}}$ と流れの状態を表すパラメータ

可能性は残っている.このずれの原因については測定方 法も含めて今後の課題である.

\section{4. まとめ}

ドライベッド上の 1 次元ダム破壊流れの流動特性とそ こに設置された迎角のない正角柱の抵抗係数について夷 験的に検討を加え, 次のような結論を得た.

(1) ダム破壊流れの方向流速分布は， $t * 50 （ t \geqq 4.2 \mathrm{~s})$ を 除き滑面対数側で表示できる.

(2) ダム破壊流れの表面流速 $V_{\mathrm{s}}$ と水深平均流速 $V$ との比 である表面流速比 $V_{s} / V$ は， $t_{*} \geqq 50$ を除き， 1.12 程度 の值を取る。この值は等流の值 $(\fallingdotseq 1.11)$ とほぼ同じ である.

(3) ダム破壊流れ中の角柱の抵抗係数 $C_{d}$ は, 水路実験と 数值実験の結果を勘案すると, $t_{*}$ の増加とともに $t_{*} \fallingdotseq$ $70 （ t \doteqdot 5.9 \mathrm{~s} ）$ までは急激に増加し，その後は緩やか に増加し等流中の角柱の抵抗係数に漸近すると予想 される. しかし， $t_{*}>70$ では $t_{*}$ に対する抵抗係数の 増加が極めて緩やかであるため, 長時間にわたって 等流の場合の約半分程度の値を取ると推察される. このように，等流に比して抵抗係数が小さくなる理 由は不明であり, 今後の課題である.

(4) 抵抗倸数比 $C_{d} / C_{d s}$ と流れの状態を表すパラメータ $\Phi$ との関係は, $t_{*}$ の増加とともに Фでほぼ表すことができる．ただし，Фが大きくな ると若干のずれが生じる.このずれの原因について は測定方法も含めて今後の課題である.

今後は, 時間が充分に経過したときの角柱に働く流
体力や迎角の影響, さらには角柱群の抵抗係数について 検討を加える予定である.

謝辞: 本研究は，文部科学省科学技術研究費補助金，基盤 研究 (B) (2) (代表 : 秋山壽一郎, 課題番号11450190) の 援助を受けた. ここに記して感謝の意を表します。

\section{参考文献}

1) 末次忠司・栗城 稔: 改良した氾濫モデルによる汇濫流の 再現と防災への応用に関する研究, 土木学会論文集, No.593/II-43, pp.41-50,1998.

2) 福岡捷二・川島幹雄・横山 洋・水口雅教 : 密集市街地の 氾濫シミュレーションモデルの開発と洪水被害軽减対策の 研究，士木学会論文集，No.600/II-44, pp.23-36,1998.

3）高橋 保・中川一・加納茂紀 : 洪水汇濫による家屋流出 の危険度評価, 京都大学防災研究所年報,第28号B-II, pp.455470, 1985.

4) 重枝未玲・秋山壽一郎・浦 勝・有田白高 : 非構造格子を 用いた有限体積法に基づく平面 2 次元洪水流数值モデル,水 工学論文集, 第45巻, pp.895-900, 2001.

5) 重枝末玲・秋山壽一郎・浦 勝・小林俊彦: 洪水汇濫流と 構造物に働く流体力の数值シミュレーション, 水工学論文 集, 第46巻, 2002 .

6) 後藤智明・首藤信夫 - 笹川稔郎 : 陸上障害物群の津波氾濫 時における抵抗第25回水理講演会論文集, pp.125-132, 1981.

7) 栗城 稔・末次 忠司・海野 仁・田中義人・小林裕明: 氾監シミュレーション・マニュアル(案), 土木研究所資料, 第3400号, 1996.

8）秋山壽一郎・重枝末玲・小林俊彦・大田和正 : 定常自由表 面流中の正角柱に働く流体力，水工学論文集，第46巻, 2002.

9) Fukui, Y., Nakamura, M. Shiraishi, H. and Sasaki,Y.: Hydraulic study on tsunami, Coastal Emg. in Japan, Vol.6, pp.67-82,1963.

10) Cross, R.H.: Tsunami surge forces, $J$. of the Waterways and Harbors Division, ASCE, WW4, pp.201-231, 1967.

11）松富英夫 : 砕波段波衝突による衝撃力について, 土木学会論 文集, 第399号/II-10, pp.147-155, 1988.

12) Cumberbatch, E.: The impact of a water wedge on a wall, Journal of Fluid Mechanics, Vol.7, pp.353-374,1960.

13) Nezu, I. and Rodi, W.: Open-channel flow measurements with a laser Doppler anemometer, Journal of Hydraulic Engineering, ASCE, Vol.112. No.5, pp.335-355, 1986.

14) Stoker, J.J.: Water Waves, Interscience Publishers, Inc. , Wiley and Sons, New York, pp.567, 1957.

(2001.10.1受付) 